\title{
THE VALUE OF LOYALTY: UNDERSTANDING BRAND LOYALTY FROM A CONSUMER POINT OF VIEW
}

\author{
Russell McKenzie ${ }^{1}$, Aristides R. Baraya ${ }^{1}$, David C. Wyld ${ }^{1}$, Carolina Garzón \\ Medina $^{2}$, and Adriana Marcela Gordillo González ${ }^{2}$ \\ ${ }^{1}$ Southeastern Louisiana University, College of Business, Hammond, Louisiana USA \\ ${ }^{2}$ Universidad Santo Tomas, Bogota, Colombia
}

\begin{abstract}
The development of brand loyalty plays an important factor in the development of marketing strategies due to the pivotal role that felt consumer loyalty holds in determining market success. From an analysis of the attitudinal, cognitive and behavioral dimension, determinants such as risk, quality and perceived price are recognized during the process of selection and purchase of consumer brands. The purpose of this article is to understand the role of consumer loyalty in relation to the purchase and consumption of brands within the modern channel through a review of the literature, in order to generate a reflective framework at the level of the retail sector.
\end{abstract}

\section{KEYWORDS}

Brand loyalty, consumer behavior, branding, marketing, purchase decision-making, strategy, sales.

\section{INTRODUCTION}

Today, companies are more concerned with retaining their customers than ever before! Turning customers into repeat, loyal buyers has become a key competitive strategy for firms of all sizes and types - one even more important on the priority scale than attracting new prospects and customers. This is squarely because it has been proven time and time again that it is far easier and cheaper to sell to current customers than to acquire new consumers (Cobo \& González, 2007). As a result, the current, hypercompetitive marketplace for consumer products is characterized by having an ever-increasing number of product offerings, forcing companies to create differentiation for their brands in order to attract the loyalty of their buyers.

In this sense, studying the behavior of the consumer implies a set of efforts related to the selection, purchase and evaluation of a particular good or service (Mollà Descals, Berenguer Contrí, Gómez Borja, \& Quintanilla Pardo, 2014). Based on this, studying the consumer in terms of brand loyalty has been of great interest, since it provides value in light of the exchange process and the effectiveness of marketing strategies.

In line with the above, we must consider some variables involved in the consumer's brand loyalty; on the one hand there is the perceived risk, this being understood as the subjective appreciation the consumer makes to the negative results of a wrong choice (Jiménez, San Martín, \& Susano, 
2012; Chia-Wu, Kai-Yu, Shu-Hao \& Jin-An, 2019). Different types of risk affect the decision and choice of purchase, such as financial, social, physical, temporary, functional and psychological (Almousa, 2011). On the other hand, other variables considered are associated with the image of the establishment, this being a relevant factor because to a certain extent the establishment is the first contact where loyalty is created (Bellenger, Steinberg, \& Stanton, 1976). Accordingly, if the retailer's image is favorable and the brand is offered within that establishment, the consumer is much more likely to make a repurchase.

In addition to the variables involved in creating brand loyalty, Jacoby \& Kyner (1973) propose three dimensions of study on the subject: 1) behavioral loyalty, which implies the repurchase of a particular product/brand; 2) attitudinal loyalty, mediated by emotions and beliefs; and 3) cognitive loyalty, associated with the regulation of consumer attention, recall and processing processes during the purchase and consumption process. Based on these dimensions, the consumption of brands in the modern channel is supported. This would be similar to the notion that all product brands manufactured by a certain firm, or even distributed by a specific distributor, that are offered to the consumer under the name or brand property of the distributor or retailer, benefit from consumer loyalty to those who project them to the market (Puelles \& Puelles,2003)

\section{Brand Loyalty From the CONSUMER's Point OF VieW}

Brand loyalty has become an important subject since it is a factor that allows the construction of links between companies and consumers, in order to guarantee competitiveness at a high level (Setó Parmíes, 2003). Loyalty is considered as a sequential process that expresses the preferences of the consumer for a particular brand, which includes the cognitive, affective and cognitive phases within the traditional scheme of purchase decision that includes different segments of customers according to the continuity with which a determined brand is purchased (Jacoby \& Chestnut, 1978).

Based on the above, brand loyalty is associated with satisfaction, understood to be a unidimensional variable connected with emotional, motivational and gratification aspects, while loyalty is considered a multidimensional variable affected by the same satisfaction (Segado, Alonso, \& Rocha, 2016; Coelhoa, Ritaa, Raposo Santos, 2018). This in cognitive terms means that if there is no satisfaction on the part of the consumer, loyalty will probably not be generated or it will be produced to a lesser extent, sustained through the repetition of the purchase. According to Colmenares \& Saavedra (2007) different levels of loyalty to brands are identified as: non-existent, feigned, latent and true loyalty (see Table 1). 
Table 1: Level of Loyalty

\begin{tabular}{|c|c|c|}
\hline \multirow[t]{2}{*}{ Repurchase } & \multicolumn{2}{|c|}{ Commitment } \\
\hline & Low & High \\
\hline Low & $\begin{array}{l}\text { No Loyalty } \\
\text { - Low loyalty } \\
\text { - Uncommitted Client } \\
\text { - Customer not interested in any } \\
\text { particular brand }\end{array}$ & $\begin{array}{l}\text { Latent Loyalty } \\
\text { - Consumers engaged } \\
\text { - Does not have a strong } \\
\text { attitude towards a particular } \\
\text { brand } \\
\text { - They do not buy or consume } \\
\text { with high preference their } \\
\text { own brand }\end{array}$ \\
\hline High & $\begin{array}{l}\text { Insincere Loyalty } \\
\text { - Relationship more than } \\
\text { voluntary dependence } \\
\text { between the consumer and } \\
\text { the brand. } \\
\text { The consumer does not } \\
\text { always have the resources } \\
\text { both in money and in time. } \\
\text { - Consumers are forced to } \\
\text { make the purchase or are } \\
\text { forced to be loyal. }\end{array}$ & $\begin{array}{l}\text { True Loyalty } \\
\text { - Purpose, intention and } \\
\text { motivation of the consumer } \\
\text { against the purchase of the } \\
\text { own brand. } \\
\text { The consumer feels highly } \\
\text { committed to buying the } \\
\text { same brand. } \\
\text { The consumer is strongly } \\
\text { influenced by the affective } \\
\text { ties, the confidence and } \\
\text { satisfaction towards the own } \\
\text { brand and its offer. }\end{array}$ \\
\hline
\end{tabular}

Source: Colmenares \& Saavedra (2007)

\section{TYPES OF LOYALTY OF OWN BRANDS}

\subsection{Cognitive Loyalty}

From the cognitive approach, loyalty is understood as the attention and concentration that a person lends to the process of purchase and consumption (Duque Oliva \& Ramírez Angulo, 2014), from which the consumer must make a favorable assessment of the attributes of the brand and the identifiers as price and characteristics compared to those of the competition (Moliner, Callarisa, \& Rodríguez, 2007). In this specific case, the loyalty base is based on a valuation that is aware of the benefits related to the purchase repetition that cause the consumer to consider its supplier as unique or exclusive (Moliner, Gil, \& Ruiz, 2009). According to Bustos \& González (2006), if a brand offers very good prices the consumer will create a cognitive loyalty because it is clearly motivated by functional characteristics since the main commitment of the consumer is related to the costs and benefits, which will produce a frequent purchase. 


\subsection{Attitudinal Loyalty}

In line with the above, attitudinal loyalty is based on behavioral theories and serve as the basis from which all the affective, cognitive and conative elements are integrated (Oliver, 1999). This describes the approach as a concept based on beliefs and pleasant feelings that drive the consumer to make a repurchase, in addition to generating strong emotional bonds that motivate the consumer to generate a preference for a certain brand (Keller, Conceptualizing, Measuring, and Managing Customer-Based Brand Equity, 1993). In this respect, the attitude allows the construction of positive feelings towards the brand, which allows the consumer to generate a strong level of commitment, thanks to several factors that allow him to create an emotional balance (Yang \& Peterson, 2004). By understanding loyalty in attitudinal terms, the consumer processes the information that comes from the stimuli of the medium (advertising, merchandising, POP material, voice to voice, etc), generating links with the brand facilitating the repurchase of the brand (Tabón \& Pérez Acosta, 2016; Naser, Lara \& Vipul,2019) or encouraging others to buy their preferred brand (Odin, Odin, \& Valette-Florence, 2001).

\subsection{Behavioral Loyalty}

The behavioral approach assumes that brand loyalty is created when someone rates a purchase as good from their own experience, ensuring the likelihood of a repurchase. In this sense, the likelihood of a repurchase increases and is adjusted to the frequency and purchasing power of the satisfied customer, that is, the more systematic the response, the more loyal the person is considered (Gómez, Martinez, Recio, \& López, 2013). In addition to this, Oliver (1999) proffers that loyalty is obtained by a process that contains four stages in which behavioral loyalty is expressed as the action of buying a particular product, preceded by important phases such as cognitive, affective and conative that support attitudes as a psychological function and that strengthen the decision of purchase by the consumer. According to Gómez, Martínez, Recio \& López (2013) behavioral loyalty represents the last instance from which the consumer makes the decision to buy or not a particular brand, determined by aspects associated with perceived risk, price and the quality of the product (see figure 1).

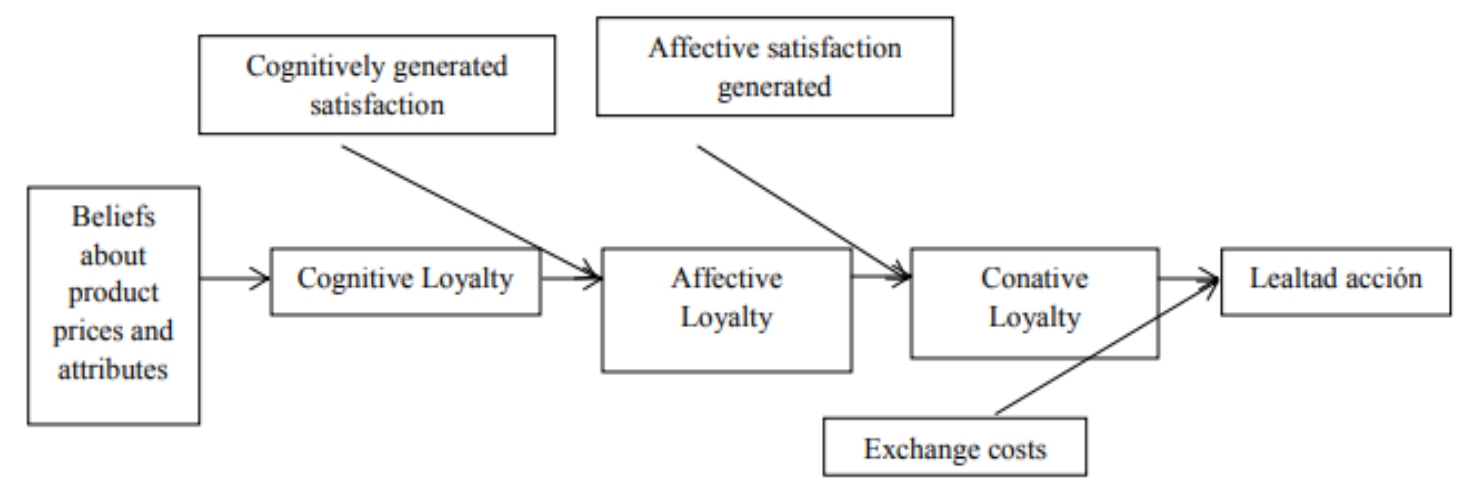

Figure 1: Oliver Model of Loyalty (1999)

Source: Moliner, Callarisa, \& Rodríguez (2007), base in Oliver (1999)

It is important to emphasize that, based on the previous model, loyalty to brands is closely linked to the consumer's perception of quality and the type of experience that the consumer develops in 
the construction of satisfactory links (Apostolos \& Pinelopi, 2018)); based on this the link between price and quality is very important.

\section{OWN BRANDS IN THE MODERN ChanNEL}

Own or store brands were created as a competitive strategy on the part of retailers and distributors as a substitute competitor to commercial (national) brands, therefore it is natural that they occupy dominant positions in store gondolas and shelves and they have greater privileges in the exhibition, since they produce higher sales and income for establishments (Silva, 2011). In countries with economic difficulties or large economic gaps it has been identified that own brands have been oriented with a very significant growth (Cabrejos, 2004). In this regard, own brands determine their positioning based on the stratification given by attributes such as price and quality, which has allowed dealers to play with the position they occupy in the gondola. In this sense according to Payan Rodriguez (2013) there are generic, imitations, premium and innovative value brands in the market (see Table 2).

Table 2: Characteristics of Own Brands According To Their Classification

\begin{tabular}{|c|c|c|c|c|}
\hline & $\begin{array}{c}\text { Generic } \\
\text { brand names }\end{array}$ & Imitation Brands & $\begin{array}{l}\text { Premium Own } \\
\text { Brands }\end{array}$ & $\begin{array}{l}\text { Brands with } \\
\text { innovative value }\end{array}$ \\
\hline $\begin{array}{l}\text { Quality for a } \\
\text { leading brand }\end{array}$ & Low quality & $\begin{array}{l}\text { Quality close to } \\
\text { that of } \\
\text { manufacturers' } \\
\text { products }\end{array}$ & $\begin{array}{l}\text { Quality equal or } \\
\text { better, is promoted } \\
\text { as best }\end{array}$ & $\begin{array}{l}\text { Functional quality at } \\
\text { the same time as the } \\
\text { leading brand but } \\
\text { the value added is } \\
\text { removed }\end{array}$ \\
\hline $\begin{array}{l}\text { Product } \\
\text { performance }\end{array}$ & None & $\begin{array}{l}\text { Designs similar } \\
\text { to those of the } \\
\text { products } \\
\text { manufacturers }\end{array}$ & $\begin{array}{l}\text { Considerable } \\
\text { effort to develop } \\
\text { better products } \\
\text { with similar or } \\
\text { better technology }\end{array}$ & $\begin{array}{l}\text { Considerable effort } \\
\text { and innovation in } \\
\text { terms of cost-benefit } \\
\text { analysis }\end{array}$ \\
\hline Packaging & $\begin{array}{l}\text { Cheap and } \\
\text { Minimal }\end{array}$ & $\begin{array}{l}\text { As close to the } \\
\text { leading brand as } \\
\text { possible }\end{array}$ & $\begin{array}{l}\text { Unique and is a } \\
\text { source of } \\
\text { differentiation }\end{array}$ & $\begin{array}{l}\text { Unique but cost- } \\
\text { effective }\end{array}$ \\
\hline $\begin{array}{l}\text { Location of } \\
\text { shelves }\end{array}$ & $\begin{array}{l}\text { Poor } \\
\text { location, } \\
\text { less visible } \\
\text { shelves }\end{array}$ & $\begin{array}{l}\text { Adjacent to the } \\
\text { leading brand }\end{array}$ & Striking positions & $\begin{array}{l}\text { Normal as in the } \\
\text { whole store }\end{array}$ \\
\hline $\begin{array}{l}\text { Advertising / } \\
\text { Promotion }\end{array}$ & None & $\begin{array}{l}\text { Frequent price } \\
\text { promotions }\end{array}$ & $\begin{array}{l}\text { Featured in } \\
\text { advertising but } \\
\text { limited in } \\
\text { promotions }\end{array}$ & $\begin{array}{c}\text { Do not have } \\
\text { promotional } \\
\text { advertising as a } \\
\text { brand }\end{array}$ \\
\hline $\begin{array}{l}\text { Consumer } \\
\text { proposal }\end{array}$ & $\begin{array}{l}\text { Sell the } \\
\text { most }\end{array}$ & $\begin{array}{c}\text { Sell with the } \\
\text { same quality but }\end{array}$ & $\begin{array}{l}\text { Sell the best } \\
\text { products on the }\end{array}$ & $\begin{array}{l}\text { Sell as the most } \\
\text { profitable product }\end{array}$ \\
\hline
\end{tabular}


International Journal of Managing Value and Supply Chains (IJMVSC) Vol. 11, No. 1, March 2020

\begin{tabular}{|l|c|c|c|c|}
\hline & $\begin{array}{c}\text { inexpensive } \\
\text { product }\end{array}$ & at a lower price & market & $\begin{array}{c}\text { but with quality } \\
\text { objectives regarding } \\
\text { the leading brands }\end{array}$ \\
\hline
\end{tabular}

Source: Payán Rodriguez (2013)

\section{CONClusion}

Consumer brand loyalty is developed from several product and store attributes and the interaction of product and store characteristics. In addition, when the consumer manages to create a link or acceptance to the establishment, the loyalty process is built and sustained: justified on the basis of price and quality, which mediate the action of selecting a particular brand, based on knowledge and attitude towards the brand which favors the construction of positive sentimental bonds by the consumer, resulting in repurchase as part of the habits of the consumer.

Usually, a purchase intention can be impacted by the education of the consumer into a brand's value and ability to satisfy customer needs. Knowledge can and does reduce risk in the purchase process. It is realized that the balance between price and quality is fundamental in customer choice and results in the habit of purchasing and repurchasing a product - which serves as a basis for brand loyalty.

\section{REFERENCES}

1. Almousa, M. (2011). Perceived risk in apparel online shopping: A multi-dimensional Perspective. Canadian Social Science, 23-31.

2. Apostolos, N., \&, Pinelopi, A. (2018). Consumer-brand relationships and brand loyalty in technology-mediated services. Journal of Retailing and Consumer Services, 40, 287-294.

3. Bellenger, D., Steinberg, E., \& Stanton, W. (1976). Congruence of store image and self-image-As it relates to store loyalty. Journal of Retailing, 17-32.

4. Cabrejos, B. (2004). Las marcas propias desde la perspectiva del consumidor final. Cuadernos de investigación, 1-148.

5. Chia-Wu, L., Kai-Yu, W., Shu-Hao, C., \& Jin-An, L. (2019). Investigating the development of brand loyalty in brand communities from a positive psychology perspective. Journal of Business Research, 99, 446-454.

6. Cobo, F., \& González, L. (2007). Las implicaciones estratégicas del marketing relacional: fidelización y mercados ampliados. Anuario jurídico y Económico Escurialense, 543-566.

7. Coelhoa, P., Ritaa, P., Raposo Santos, C. (2018). On the relationship between consumer-brand identification, brand community, and brand loyalty. Journal of Retailing and Consumer Services, 43, 101-110.

8. Colmenares, O., \& Saavedra , J. (2007). Aproximación teórica de la lealtad de marca: enfoques y valoraciones. Cuadernos de Gestión, 7(2), 69-81.

9. Duque Oliva, E. J., \& Ramírez Angulo, P. J. (2014). Evolución conceptual y relación entre involucramiento y lealtad. Suma de Negocios, 169-179. 
International Journal of Managing Value and Supply Chains (IJMVSC) Vol. 11, No. 1, March 2020

10. Gómez, D., Martínez, E., Recio, R., \& López, H. (2013). Loyalty, satisfaction and academic performance of UASLP-UAMZM students. Sophia, 9, 1-17.

11. Jacoby, J., \& Chestnut, R. (1978). Brand loyalty: Measurement and management. John Wiley \& Sons Incorporated, 1-9.

12. Jacoby, J., \& Kyner, D. (1973). Brand loyalty vs. repeat purchasing behavior. Journal of Marketing Research, 1-9.

13. Jiménez, N., San Martín, S., \& Susano, J. (2012). El etnocentrismo y el riesgo percibido del consumidor mexicano. Ciencia UAT, 7, 34-40.

14. Moliner, B., Gil, I., \& Ruiz, M. E. (2009). La formación de la lealtad y su contribución a la gestión de destinos turísticos. Cuaderno de administración, 75-98.

15. Moliner, M. Á., Callarisa, L., \& Rodríguez, R. (2007). La explicación del comportamiento de lealtad desde la teoría de la actitud: una aplicación a usuarios de hospitales. Decisiones de Marketing, 1-10.

16. Mollà Descals, A., Berenguer Contrí, G., Gómez Borja, M. Á., \& Quintanilla Pardo, I. (2014). Comportamiento del consumidor. Barcelona: UOC.

17. Naser, P., Lara, S., \& Vipul, P. (2019). Brand attribute associations, emotional consumer-brand relationship and evaluation of brand extensions. Australasian Marketing Journal. Advance online publication. https://doi.org/10.1016/j.ausmj.2019.07.004.

18. Odin, Y., Odin, N., \& Valette-Florence, P. (2001). Conceptual and operational aspects of brand loyalty: an empirical investigation. Journal of Business Research, 75-84.

19. Oliver, L. (1999). Whence consumer loyalty? Journal of Marketing, 63 (Special Issue).

20. Payán Rodríguez, C. F. (2013). Las marcas propias en Colombia. La Propiedad Inmaterial, (17), 163-186.

21. Puelles, J., \& Puelles, M. (2003). Marcas de distribuidor. Distribución y Consumo, 55-71.

22. Segado, F., Alonso, J., \& Rocha, M. (2016). Relación entre satisfacción y lealtad de los usuarios de campamentos náuticos. International Journal of Medicine and Science of Physical Activity and Sport, 17-32.

23. Setó Parmíes, D. (2003). La fidelidad del cliente en el ámbito de los servicios: un análisis de la escala intenciones de comportamiento. Investigaciones Europeas de Dirección y Economía de la Empresa 9(2), 189-204.

24. Silva, H. (2011). Comportamiento de las superficies de retail en Colombia. Pensamiento y gestión (30), 3-20.

25. Tabón, S., \& Pérez Acosta, A. (2016). El papel de la discriminación de estímulos en la lealtad hacia un producto de consumo masivo. Universidad \& Empresa, 85-101. 
International Journal of Managing Value and Supply Chains (IJMVSC) Vol. 11, No. 1, March 2020

\section{AUTHORS}

Dr. Russell McKenzie is an Associate Professor of Economics at Southeastern Louisiana University. His research interests include consumer economics, real estate and natural resource planning and use.

Dr. Aristides R. Baraya is the Director of the Latin American Business Development Initiative at Southeastern Louisiana University. His research interests includes youth entrepreneurship, international management, Hispanic advances and leadership.

Dr. David C. Wyld is the Merritt Professor of Management at Southeastern Louisiana University. His research interests include issues at the intersection of technology advances and demographic change as they impact strategic management and marketing.

Mrs. Carolina Garzón Medina is a faculty member at University Santo Tomas, Bogota Colombia. Her research interests include marketing strategies, consumer psychology, cultural and consumption.

Mrs. Adriana Marcela Gordillo is a faculty member at University Santo Tomas, Bogota Colombia. Her research interests center around marketing and brand management. 